\title{
Um Aleksander Púshkín (1799-1837) og „Stöðvarstjórann“ (1830)
}

\begin{abstract}
A leksander Púshkín nýtur pess heiðurs að vera nefndur pjóð- Iskáld Rússa. Hans er fyrst og fremst minnst sem ljóoskálds í heimalandi sínu en á sîđari hluta höfundarferilsins jókst áhugi hans á prósaskrifum og sendi hann frá sér nokkrar smásögur og sögulegar skáldsögur. Ofmælt er að segja að Púshkín sé upphafsmaður rússneskra bókmennta en pó er framlag hans til peirra af slíkri stærðargráđu að hann má án efa telja föđur nútímabókmennta í heimalandi sínu og verk hans, bæði í bundnu og óbundnu máli, höfðu óafmáanleg áhrif á próun rússneskra bókmennta. Púshkín réðst djarfur til verka á peim ökrum sem á vegi hans urðu, plægðum jafnt sem óplægðum. Hann vann á sjálfstæðan hátt úr pjóðsagna- og ævintýraarfi Rússlands, sögulegum efnum og erlendum fyrirmyndum. Raunsæi og rómantík, ástir og afbrýði, sálfræði og eðli manneskjunnar, svik og dauði, handanlífið og bókmenntirnar sjálfar - allt á petta sinn sess í verkum pessa merka höfundar. Að auki veltir hann fyrir sér málefnum líðandi stundar, stöðu ólíkra stétta og hlutverki skáldsins gagnvart listinni, pjóðinni og keisaranum, svo eitthvað sé nefnt.
\end{abstract}

Skáldverk Púshkíns hafa fram til pessa dags verið óprjótandi innblástur nýrra verka, hvort heldur sem er á sviði tónlistar, leikritunar, mynd- og kvikmyndalistar eða bókmennta. Rússnesk 19. aldar tónskáld sem byggðu á verkum Púshkíns hafa borið hróður hans um veröld vída og má par nefna óperurnar Jevgení Onegín (1879) og Spadadrottninguna (1890) eftir Pjotr Tsjakovskí, og Borís Godúnov (1874) eftir Modest Músorgskí, auk fjölda sönglaga og rómansa. 
Eftir pví sem Púshkín náði meiri proska sem ljóðskáld varð prósinn, próun hans og möguleikar, honum æ hugleiknari. Af sögum hans er "Spaðadrottningin“1 (1833) líklega pekktust en sögurnar fimm í smásagnasafninu Sögur Belkins hafa einnig notið mikilla vinsælda. „Stöðvarstjórinn“ (rússn. „Станционный смотритель“), sem nú birtist í fyrsta sinn á íslensku, er ein pessara sagna sem skáldið skrifaði haustið 1830 í Boldino og gaf út sama ár. ${ }^{2}$

Sagan gerist fyrir tíma lestarferða og pví ferðast menn á hestvögnum. Net póststöðva var um landið og par réðu ríkjum embættismenn af stétt stöðvarstjóra. Hlutverk peirra var m.a. að taka við preyttum ferðalöngum og setja hesta peirra á hús og fódur í skiptum fyrir ópreytta hesta. Staða og embætti peirra sem á ferð voru sagði til um hve marga hesta peir áttu að fá á hverri stöð. Allt var petta skráð í sérstaka ferðapappíra og ferðabók sem hver og einn hafði meðferðis. Líkt og fram kemur í sögunni gat gengið á ýmsu, veðrið var oft vont og vegirnir enn verri, pjónustan misgóð og ekki alltaf öruggt að ferðalangar gætu gengið að ópreyttum hestum. Stöðvarstjórarnir máttu oft pola skammir og ruddaskap um leið og peir reyndu að halda í pau völd sem peir pó höfðu.

Stöðvarstjórarnir sátu í 14. og neðsta prepi svokallaðs Virðingarstiga, sem var embættismannakerfi sem Pétur I. kom á fót árið 1720. Petta kerfi, með tilheyrandi titlatogi, ósanngirni, smjaðri, mikilmennskutilburðum og undirlægjuhætti, átti eftir að verða frjór jarðvegur fyrir rithöfunda í Rússlandi. Um leið og Púshkín snýr hér með óvæntum hætti út úr pemanu um fátæku stúlkuna, sem dregin er á tálar af háttsettu glæsimenni og skilin eftir svikin og niðurlægð, leiðir hann fram nýja hetju í líki Samsons Vírín afurð Virðingarstigans - sem átti eftir að geta af sér heimspekkta eftirmenn. Par má helsta nefna Akakí Akakíjevíts, aðalpersónu Níkolajs Gogol í „Kápunni“ (1841), og Makar Devúshkín, söguhetju Dostojevskís í skáldsögunni Fátcekt fólk (1846). Allar pessar

1 „Spaðadrottningin“ hefur oftar en einu sinni verið prentuð á íslensku. Úr frummálinu var sagan ekki býdd fyrr en 2017 og birtist pá ásamt fleiri býdingum Áslaugar Agnarsdóttur úr rússnesku í bókinni Sögur frá Rússlandi, sem Ugla gaf út árið 2017.

2 Um pýðingasögu sagnanna í safninu Sögur Belkins, og um safnið sjálft, má lesa í: Rebekka práinsdóttir: „Um Alexander Púshkín og Sögur Belkíns“, Milli mála 6/2014, bls. 135-140. Í sama hefti birtust í fyrsta sinn býðingar á tveimur sagnanna úr frummálinu; „Skotið“ og „Líkkistusmiðurinn“. 
persónur tilheyra peirri manngerð rússneskra bókmennta sem kölluð hefur verið „litli maðurinn“. Litli maðurinn gegnir lágu embætti, gjarnan í neðstu prepum Virðingarstigans. Hann sinnir starfi sínu af alúð og leitast við að skapa sér sæmilegt líf prátt fyrir lítil efni. Hann er á undarlegan hátt ógæfusamur, vanmáttugur og lítill í sér og pegar í harðbakkann slær er pessari manngerð flest mótdrægt: ruddaskapur annarra, niðurlægingin og kerfið allt, og enginn og ekkert kemur honum til hjálpar. Pegar hann reynir að andmæla er раð dæmt til að mistakast; litla manninn skortir sjálfstraust, vald og bakland til að fá sínu framgengt. Hann hopar, missir fótanna og hverfur af sjónarsviðinu, en öðlast um leið eilíft líf í hugum lesenda og par með bókmenntanna. 